OPEN ACCESS

Edited by:

Roger Frutos,

Université de Montpellier, France

Reviewed by:

Peng Zhang,

Hong Kong Polytechnic University,

Hong Kong

Tianmu Chen,

Xiamen University, China

${ }^{*}$ Correspondence:

Michael C. Jarvis

michael.jarvis@glasgow.ac.uk

Specialty section:

This article was submitted to Infectious Diseases - Surveillance,

Prevention and Treatment,

a section of the journal

Frontiers in Public Health

Received: 31 July 2020

Accepted: 30 October 2020

Published: 23 November 2020

Citation:

Jarvis MC (2020) Aerosol

Transmission of SARS-CoV-2:

Physical Principles and Implications.

Front. Public Health 8:590041.

doi: 10.3389/fpubh.2020.590041

\section{Aerosol Transmission of SARS-CoV-2: Physical Principles and Implications}

\author{
Michael C. Jarvis* \\ School of Chemistry, Glasgow University, Glasgow, United Kingdom
}

Evidence has emerged that SARS-CoV-2, the coronavirus that causes COVID-19, can be transmitted airborne in aerosol particles as well as in larger droplets or by surface deposits. This minireview outlines the underlying aerosol science, making links to aerosol research in other disciplines. SARS-CoV-2 is emitted in aerosol form during normal breathing by both asymptomatic and symptomatic people, remaining viable with a half-life of up to about an hour during which air movement can carry it considerable distances, although it simultaneously disperses. The proportion of the droplet size distribution within the aerosol range depends on the sites of origin within the respiratory tract and on whether the distribution is presented on a number or volume basis. Evaporation and fragmentation reduce the size of the droplets, whereas coalescence increases the mean droplet size. Aerosol particles containing SARS-CoV-2 can also coalesce with pollution particulates, and infection rates correlate with pollution. The operation of ventilation systems in public buildings and transportation can create infection hazards via aerosols, but provides opportunities for reducing the risk of transmission in ways as simple as switching from recirculated to outside air. There are also opportunities to inactivate SARS-CoV-2 in aerosol form with sunlight or UV lamps. The efficiency of masks for blocking aerosol transmission depends strongly on how well they fit. Research areas that urgently need further experimentation include the basis for variation in droplet size distribution and viral load, including droplets emitted by "superspreader" individuals; the evolution of droplet sizes after emission, their interaction with pollutant aerosols and their dispersal by turbulence, which gives a different basis for social distancing.

Keywords: evaporation, wind, turbulence, ventilation, ultraviolet, mask

\section{INTRODUCTION}

Liquid or solid particles $<5-10 \mu \mathrm{m}$ in diameter are classed as aerosol-sized and remain suspended in the air over times of seconds to hours (1), whereas particles or droplets above this threshold diameter settle quickly out of still air onto surfaces. Contrary to initial guidance (2), there is growing evidence that airborne transport in aerosol particles is significant in the spread of SARS-CoV-2, in addition to infection via larger droplets from coughing or sneezing via and surface deposits (fomites) (3). It was initially questioned whether SARS-CoV-2 was viable in aerosols, and thus whether the presence of infective virus could be inferred from viral RNA $(1,4)$. A number of studies have now shown that the virus does remain viable in aerosols with a half-life of about an hour indoors (5-8). Because aerosol transmission does not require coughing but 
is possible through normal breathing $(9,10)$, asymptomatic individuals, known to be carriers of COVID-19 infection (11), can infect others by this route (12-14). The quantitative importance of aerosol transmission relative to transmission by other routes is still under debate (15-17) and may vary between environments, but the precautionary principle demands that measures to block this transmission route should be vigorously adopted (18). The behavior of aerosols in indoor and outdoor environments differs in its physical basis from the behavior of larger droplets (1), and different, additional containment measures are therefore needed $(19,20)$.

This minireview covers mechanisms of aerosol emission, evolution and transport, together with some implications for SARS-CoV-2 transmission in non-clinical public buildings and transportation. Transmission in hospital settings, including generation of aerosols during clinical procedures involving COVID-19 patients, and fecal bioaerosols from toilets are excluded, having been reviewed elsewhere (21-24).

The literature survey was based on Web of Knowledge searches, including "snowball" searching, up to August 2020. Preprints that have not yet been peer reviewed are excluded.

\section{PHYSICAL PRINCIPLES}

\section{Aerosol Generation}

During coughing and sneezing, liquid droplets with a wide diameter range from sub- $\mu \mathrm{m}$ to $>100 \mu \mathrm{m}$ are atomised from saliva and from fluids further down the respiratory tract $(25,26)$. It is now recognized that normal breathing and speech atomise droplets also $(9,27-29)$. Half a minute of speech releases a liquid volume comparable to a cough (10). The volume of droplets emitted during speech depends on loudness $(30,31)$ and may be greater during singing $(1,30)$. The breath emission rate is considerably increased during physical exercise (32).

The formation of aerosols and larger droplets within the respiratory tract, involving disruption of mucus layers by abrupt airflows, has been reviewed $(10,25,33)$. The details differ between the lower respiratory tract, which is the principal atomisation site during normal breathing $(25,34)$, and the laryngeal and oral/nasal regions where further droplets are created during speech, coughing and sneezing (35-37). Each site has a characteristic droplet size range $(10,36)$. Aerosol-sized $(\sim 1-3 \mu \mathrm{m})$ droplets are produced in the lower respiratory tract and the laryngeal region (36), and any larger bronchial droplets may be redeposited before exhalation (38). Large droplets up to $500 \mu \mathrm{m}$ come from the oral and nasal cavities $(35,36)$. When generated by speech these vary with loudness $(30,36)$ and articulation $(30,31,35,39)$.

Overall droplet size distributions for speech, coughing and sneezing depend on the relative contributions of each site of origin. However, caution is needed. Published size distributions vary greatly due to differing instrumental sensitivity, especially for large droplets, and wide variation between individuals (27, 40, 41). Droplet size distributions can be continuous (26), bimodal $(42,43)$, or trimodal $(27,36)$. They are often presented on a number basis (36), which is more robust than a volume-weighted basis when comparing measurements by methods that vary in their upper diameter limit. Figure 1 shows that a broad or bimodal size distribution is very different when presented on number and volume-weighted bases. It might be suggested that volume-weighted distributions (26) give a better indication of how the virus is distributed across the spectrum of droplet sizes, but that assumes the largest droplets are adequately measured and the viral concentration is constant whatever the droplet size and origin, which it is not (44): the disease progresses downward from the nasal region (45), therefore the origin and droplet size range of exhaled virus changes with disease progression. Other influences include effects of infection on airway surfaces $(34,40,46,47)$ age $(45,48)$ and conceivably viral genotype $(49)$.

It would be useful to know whether "superspreader" events $(40,50)$ involve specific droplet size distributions, large emitted volumes, high viral load or a combination of these factors. Very wide variation between subjects $\left(\mathrm{x} 10^{5}\right.$ or more) has been observed for droplet volumes emitted during breathing (51) and for viral load $(25,27-29,33,36,40,46,52-54)$.

\section{Drying of Aerosol Droplets}

Droplets are exhaled in water-saturated air and dry quickly to what in the medical literature is called a droplet nucleus (27). Particularly for an initial diameter of some tens of $\mu \mathrm{m}$, drying can convert droplets large enough to settle out of the air into aerosolsized particles that remain suspended (55). Whether droplets dry on the relevant timescale of seconds can depend on either kinetics or thermodynamics. The kinetic effect is the dominant factor for large droplets, whereas the thermodynamic effect [i.e., the equilibrium water content of the droplet in contact with the ambient air], is dominant for aerosol-sized droplets (55).

Aerosol evaporation kinetics are well-understood in combustion science. In the size range above $1 \mu \mathrm{m}$ the evaporation rate depends on the square of the diameter $\left(D^{2}\right.$ rule) (56) and on temperature (56). For water droplets it also depends on absolute humidity (57) and turbulent flow (58). The drying conditions are not constant, because the temperature and humidity of the breath or cough plume decrease as it mixes with ambient air (32). In dry air $1 \mu \mathrm{m}$ droplets dry in milliseconds, $10 \mu \mathrm{m}$ droplets in tenths of second and $100 \mu \mathrm{m}$ droplets in about $1 \mathrm{~min}$ (10). For comparison, $10 \mu \mathrm{m}$ droplets take several minutes to settle to the floor from $1.5 \mathrm{~m}$ in still air (57), whereas $100 \mu \mathrm{m}$ droplets settle in about $5 \mathrm{~s}(10)$. The settling has been visualized by laser sheet imaging $(28,43)$.

After $1 \mathrm{~s}$, droplets of aerosol size, $<5-10 \mu \mathrm{m}$, have had time to dry to equilibrium. Their equilibrium moisture content depends on the relative humidity, their salt content which determines the water activity, and for smaller particles, their size through the Kelvin effect (55). Exhaled droplets become completely dry at 50-70\% relative humidity and their equilibrium water content increases, roughly exponentially, at higher relative humidity levels $(42,59)$. Droplet drying, along with settling and entrainment in cough airflows, has been modeled by computational fluid dynamics $(55,60,61)$ to make important predictions about virus transmission in confined settings. In some of these studies $(60,61)$, an unrealistically high salt content was assumed $[100 \mathrm{~g} / \mathrm{L} \mathrm{NaCl}$, compared with $<10 \mathrm{~g} / \mathrm{L}$ salts in saliva (62)] so that the dry diameter and settling rate were 

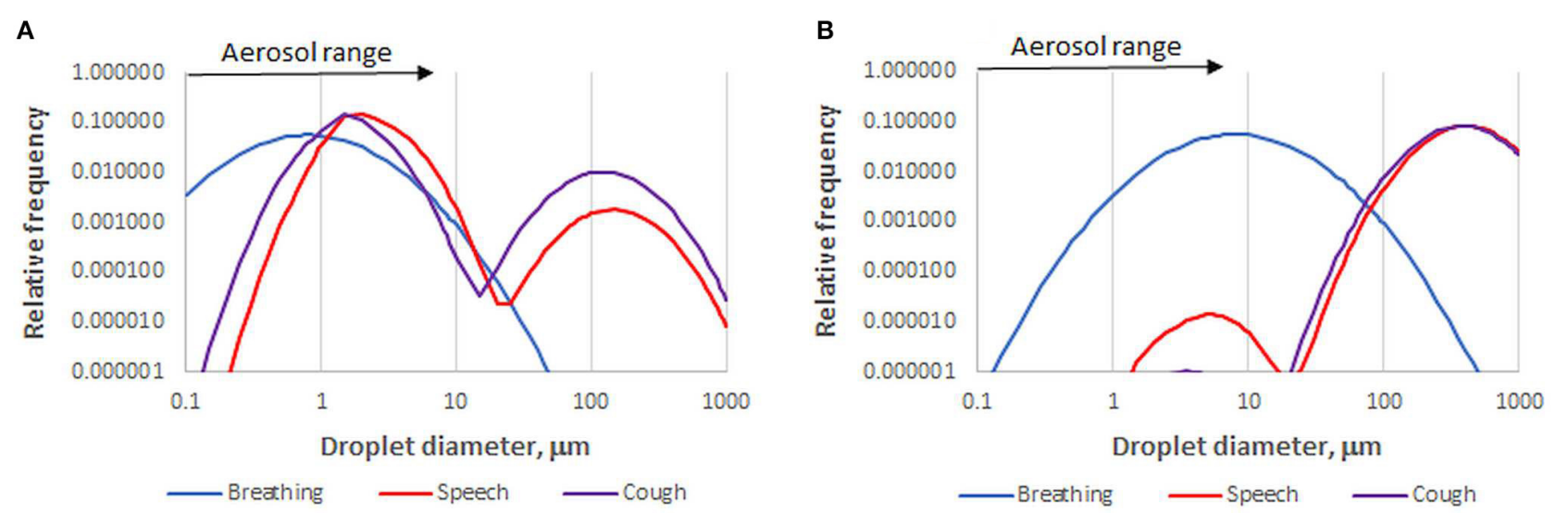

C

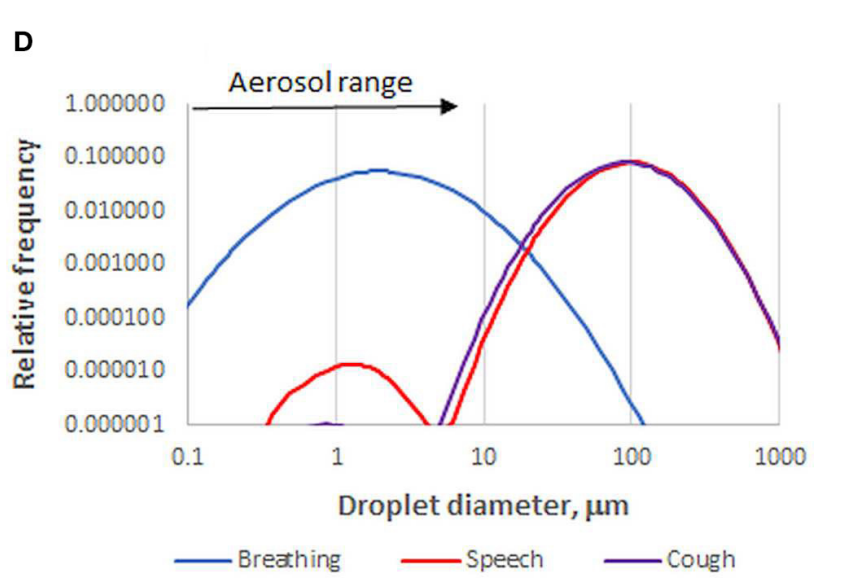

FIGURE 1 | Number-based (A) and volume-weighted (B) diameter distributions for one data set of droplets emitted by healthy subjects during breathing, speech, and coughing [Sneezing gives a distribution similar to coughing but with more $>100 \mu \mathrm{m}$ droplets (26, 43)]. Data recalculated from (36). A skew to larger diameter is inherent in volume weighting. For example, speech droplets within the aerosol size range in this data set comprise $96 \%$ of the total number but only $0.01 \%$ of the total volume. The corresponding fully dried droplet diameter distributions (C,D) are based on the assumption that the volume of dried solutes is $1.4 \%$ of the original droplet volume.

considerably overestimated. A droplet with $1.4 \%$ solids content, mainly organic (55), is reduced in diameter by a factor of about four on complete drying (Figure 1).

Drying equilibria for aerosol droplets are also modeled in atmospheric science, where the term droplet nucleus is not used but the concept is well-understood, and the effect of salt composition is modeled more rigorously (59) than in the medical literature. Adopting this approach, it can be shown that substituting an equivalent $\mathrm{NaCl}$ concentration for the complex ionic composition of saliva (62) is a poor approximation that leads to overestimation of partially hydrated diameter in the most detailed published drying model (55). Saliva also contains surfactant proteins (63) which may influence the Kelvin effect and hence the equilibrium hydration of small aerosol particles.

These issues may be responsible for a quantitative discrepancy in drying behavior observed between saliva and simple aqueous media (55) although the drying curves published for cough droplets (42) and natural aerosol droplets (59) are qualitatively similar. Saliva also contains $1-2 \%$ glycoproteins and mucopolysaccharides (27), which have been considered simply as insoluble solids contributing to the size of the droplet nucleus (55). Such polymers also contribute viscosity and are known to hinder the rehydration of dried residues, at least at macroscopic length scales (64). They might therefore retard the rehydration of aerosol nuclei when the humidity rises on inhalation, allowing them to lodge deeper in the respiratory tract.

\section{Coalescence and Fragmentation of Droplets}

Droplets are generated when surface fluid is detached and fragmented in the strong airflows of sneezing, coughing, and speech $(25,26)$. Fragmentation continues in the shear field of the violently expelled air $(37,65)$, prolonged by the viscoelasticity of the mucus polymers (66). In turbulent airflows, collisions between droplets can lead to either fragmentation or coalescence. Collisions occur when large droplets are pulled through a mist of small droplets by gravity, as in rain clouds, or by centrifugal force in turbulent eddies. Colliding droplets may fuse or may separate again, leaving a spray of smaller droplets between them $(67,68)$. 
The outcome of droplet collisions can be affected by electrostatic effects but if significant, these are hard to predict (69). There are large non-intuitive effects of surfactants (70) and viscosity (71) that might be relevant to droplets containing SARS-CoV-2.

Exhaled aerosols can also coalesce with natural water droplets (mist) or with solid or liquid pollution particulates (smoke or smog). SARS-CoV-2 sorbed on air particulates has been observed (72). There is mounting evidence for association of Covid-19 outbreaks with conditions where there are high levels of particulate pollution in the size range $0.2-10 \mu \mathrm{m}$ (73). Such associations been observed in Italy (74-76), China (77), the USA (78), and Iran (79). How air pollution might enhance transmission of SARS-CoV-2 is not clear: effects on the respiratory physiology of recipients (80) are not excluded (76). The reactive environment of smog particles (81) does not seem likely to enhance the stability of viruses, but sorption into porous carbon (soot) particles would give protection from sunlight. The mechanism of interaction of SARS-CoV-2 with airborne particulates is a current research gap. Until more is known it would seem prudent to segregate pedestrians from traffic in places like busy city streets and around school entrances. In less developed regions, the combination of poorly ventilated housing and smoke from cooking fires may exacerbate infection hazards (82).

\section{Virus Stability and Inactivation in Aerosols}

SARS-CoV-2 is viable with a half-life of approximately an hour in artificially generated aerosols $(5,7,83)$ much shorter than on hard surfaces $(6,8,84)$. A preprint suggests some residual viability up to almost a day, longer than for other coronaviruses (85). Many viruses are sensitive to temperature and humidity (86) but effects of humidity on SARS-CoV-2 in aerosols have been considered quite small $(5,7)$, in contrast to its effect on viability in surface residues (84). A suggestion that SARS-CoV-2 is inactivated by specific combinations of temperature and humidity needs experimental confirmation (87). Strong sunlight reduces the halflife in aerosols to $2-3 \mathrm{~min}(7)$. The UV component of sunlight is likely to be responsible (88). UVB and UVC do not pass through window glass. UVC radiation is in general the most effective waveband for virus inactivation (89).

\section{Transport of Aerosols in Moving Air}

Large $(>50 \mu \mathrm{m})$ droplets are directly infective only if they reach another person before settling below face height $(46,55)$. That is the idea underlying social distancing guidelines of 1 or $2 \mathrm{~m}$, although violent coughing or sneezing can carry the virus $>2 \mathrm{~m}$ (90). Aerosol particles move with the air. Remaining infective for an hour or more, they can potentially travel much greater distances in that time (10), although social distancing is still effective because the virus concentration is reduced by dispersion (91). Using published data for vertical and horizontal dispersion of a cough jet (55) and assuming similar dispersion along the jet axis, the aerosol concentration appears to fall by a factor of about 7 from $1 \mathrm{~m}$ distance to $2 \mathrm{~m}$ distance from the source, roughly in line with existing social distancing measures based on largedroplet trajectories. However, an important gap in our knowledge is how the effectiveness of dispersion depends on environmental conditions, particularly turbulence: an infectious cloud in gentle convection movement, for example, might stay compact over comparatively long distances.

In still air the plume of warm breath rises above the emitting person (10), and even the aerosol fraction projected during a cough rises slightly (55). Thus, a person standing is more exposed to aerosol infection from a person sitting, the converse of infection by larger droplets. Opening and closing doors moves aerosols from room to room (10) and a person walking tows a potentially infective wake behind them $(10,92)$, in which the turbulent airflow is complex with a tendency to draw downward behind the head (93). Wind obviously carries and disperses aerosols, and its turbulence may keep larger particles airborne (61). Downwind infection is therefore a hazard, for example in street cafes, but wind movements in built-up environments are complex and difficult to model. Modeling of the transport of environmental pollutants [e.g., (94, 95)] may provide a starting point.

\section{PRACTICAL IMPLICATIONS FOR COVID-19 CONTROL}

\section{Implications for Ventilation}

The survival of SARS-CoV-2 in aerosol form means that ventilation can have both positive and negative impacts. In an enclosed space, the airborne viral concentration from an infected person will build up over time to a level that depends on the ratio of the emission rate (44) to the number of fresh-air exchanges per hour $(23,96)$. The risk then depends on the duration of exposure (16) as well as the fresh air ventilation rate. Conversely, longdistance indoor transport by natural or mechanical ventilation is a potential hazard that does not exist for infection by larger droplets $(23,97,98)$.

To minimize infection, heating and ventilation in public buildings and in transportation may need to be modified or operated in different ways from those intended at installation (87). This provides opportunities for rapid, simple interventions $(17,99-102)$. These were noted by the building services industry at an early stage of the pandemic, and detailed practical guidance is available for an American context $(101,102)$ and from trade associations in Europe $(103,104)$ and the UK (105). Hospital ventilation is not considered here because it is designed to prevent infection (86).

The principle that air should move from clean to potentially contaminated spaces (100) is more difficult to implement when it is not known who is infected. If possible, air should not flow from any person toward other people, especially at face height. Aboveseat ventilators on coaches $(60)$ and aircraft $(19,106)$ may cause exactly that if used inappropriately. In public buildings, clean air may be obtained by recirculating through HEPA filters $(19,102$, $107,108)$ or by ventilating with outside rather than recirculated air $(103,105)$ or simply by opening windows (102), accepting that indoor air temperatures may then be colder than guideline limits in winter or hotter in summer. Old and repurposed buildings are particularly challenging and may need to be individually assessed for potential hazards. Portable air filtration units may 
have applications in these settings (107-110). Intelligently placed screens (111) may be effective in reducing exposure by disturbing the airflow. Air conditioning or heating set to recirculate may also transfer aerosols between car or taxi passengers (19).

\section{Implications for Virus Inactivation}

Unless SARS-CoV-2 can be inactivated by changing humidity or temperature (87), UV radiation seems more promising (7, 112 ). It would be helpful to know more about the wavelength sensitivity of the virus (7) for insights into effects of weather (113) and of opening windows to let sunlight UV enter. Within the limitation of their direct hazard to humans, UVC lamps as used in the food industry are a promising countermeasure $(88,89)$, although they have not prevented COVID-19 clusters centered on meat processing plants (114). UVC radiation may have value in treatment of aerosols in unoccupied spaces such as lift shafts, ventilation ducts and beamed under high ceilings where rising aerosols collect $(112,115-117)$. There could be opportunities to programme UV lamps in lift compartments, stairwells and corridors to switch off when motion sensors switch lighting on.

\section{Implications for Mask Design}

There is epidemiological evidence that masks reduce infection, even when imperfect $(118,119)$. Any face covering will catch large droplets from a cough or sneeze (120), but aerosol particles follow the airflow and escape through any gaps at the edges (19). Good fit is therefore important $(121,122)$. It might be expected that aerosols would be challenging to filter because the droplet diameter is smaller than the mesh size. However, the choice of filter materials depends on some quite complex physics including coagulation, surface adhesion (123) electrostatic interactions (124). A fairly wide range of multilayer filters (125-127) and even some combinations of natural fibers $(121,126)$ seem to give worthwhile filtration of aerosol-size particles in practice. Even single cloth layers that do not capture aerosols reduce the range of exhaled air $(119,122,128)$, Rapid screens for filtration efficiency are available $(129,130)$. There is no support for the argument that aerosol transmission makes masks useless (120).

\section{REFERENCES}

1. Anderson EL, Turnham P, Griffin JR, Clarke CC. Consideration of the aerosol transmission for COVID-19 and public health. Risk Anal. (2020) 40:902-7. doi: 10.1111/risa.13500

2. WHO. Modes of transmission of virus causing COVID-19: implications for IPC precaution recommendations. (2020). Available online at: https://www.who. $\mathrm{int} /$ news-room/commentaries/detail/modes- of-transmission- of-viruscausing-covid-19-implications-for-ipc-precaution-recommendations (accessed September 21, 2020).

3. Morawska L, Cao J. Airborne transmission of SARS-CoV-2: The world should face the reality. Environ Int. (2020) 139:105730. doi: 10.1016/j.envint.2020.105730

4. Lewis D. Is the coronavirus airborne? Experts can't agree. Nature. (2020) 580:175. doi: 10.1038/d41586-020-00974-w

5. Smither SJ, Eastaugh LS, Findlay JS, Lever MS. Experimental aerosol survival of SARS-CoV-2 in artificial saliva and tssue culture media at medium and high humidity. Emerg Microbes Infect. (2020) 9:1415-17. doi: 10.1080/22221751.2020.17 77906

\section{DISCUSSION}

Airborne transmission of SARS-CoV-2 is a significant factor in the pandemic, not yet tightly quantified but possibly comparable in magnitude to the accepted transmission routes via large droplets and surface deposits. Accumulation of infective aerosols in indoor spaces where ventilation is inadequate or largely recirculated means that exposure time is a key factor (16), and helps to explain why asymptomatic individuals, including young people, participate in the transmission chain (14). Social distancing (91) and well-fitting masks (121) help to reduce aerosol transmission as well as large droplet transmission, but other precautions specific to aerosols are also needed. These could include operational changes to ventilation systems in public buildings and public transport (98-101), UV lamps in some indoor locations $(112,116,117)$, and attention to wind (61) and sunlight (7) in outdoor settings.

New knowledge about SRAS-CoV-2 is desperately needed, and is accumulating fast. Some knowledge gaps identified here include the nature of "superspreader" events; experimental data on the evolution of droplet size after emission; coalescence with air pollutants; effective wavebands of UV radiation; and the dispersal of aerosols in airflows, influencing requirements for social distancing.

\section{AUTHOR CONTRIBUTIONS}

The author confirms being the sole contributor of this work and has approved it for publication.

\section{ACKNOWLEDGMENTS}

The author thanks the publishers for waiving open access charges within their initiative for manuscripts submitted in response to the COVID-19 pandemic.

6. Ren S-Y, Wang W-B, Hao Y-G, Zhang H-R, Wang Z-C, Chen Y-L, et al. Stability and infectivity of coronaviruses in inanimate environments. World J Clin Cases. (2020) 8:1391-9. doi: 10.12998/wjcc.v8.i8.1391

7. Schuit M, Ratnesar-Shumate S, Yolitz J, Williams G, Weaver W, Green B, et al. Airborne SARS-CoV-2 is rapidly inactivated by simulated sunlight. J Infect Dis. (2020) 222:564-71. doi: 10.1093/infdis/jiaa334

8. Van Doremalen N, BushmakerT, Morris DH, Holbrook MG, Gamble A, Williamson BN, et al. Aerosol and surface stability of SARS-CoV2 as compared with SARS-CoV-1. N Engl J Med. (2020) 382:1564-7. doi: 10.1056/NEJMc2004973

9. Borak J. Airborne transmission of COVID-19. Occup Med. (2020) 370:303-4. doi: 10.1093/occmed/kqaa080

10. Wei JJ, Li YG. Airborne spread of infectious agents in the indoor environment. Am J Infect Control. (2016) 44:S102-8. doi: 10.1016/j.ajic.2016.06.003

11. Lee S, Meyler P, Mozel M, Tauh T, Merchant R. Asymptomatic carriage and transmission of SARS-CoV-2: what do we know? Can J Anaesth. (2020). 2:1-7. doi: 10.1007/s12630-020-01729-x

12. Chen W, Zhang N, Wei J, Yen H-L, Li Y. Short-range airborne route dominates exposure of respiratory infection during close contact. 
Build Environ. (2020) 176:106850. doi: 10.1016/j.buildenv.2020.1 06859

13. Asadi S, Bouvier N, Wexler AS, Ristenpart WD. The coronavirus pandemic and aerosols: does COVID-19 transmit via expiratory particles? Aerosol Sci Technol. (2020) 54:635-8. doi: 10.1080/02786826.2020.1749229

14. Sugano N, Ando W Fukushima W. Cluster of SARS-CoV-2 infections linked to music clubs in Osaka, Japan: asymptomatically infected persons can transmit the virus as soon as 2 days after infection. J Infect Dis. (2020) 222:1635-40. doi: 10.1093/infdis/jiaa542

15. Jones RM. Relative contributions of transmission routes for COVID-19 among healthcare personnel providing patient care. J Occup Environ Hyg. (2020) 17:408-15. doi: 10.1080/15459624.2020.1784427

16. Vuorinen V, Aarnio M, Alava M, Alopaeus V, Atanasova N, Auvinen M, et al. Modelling aerosol transport and virus exposure with numerical simulations in relation to SARS-CoV-2 transmission by inhalation indoors. Saf Sci. (2020) 130:104866. doi: 10.1016/j.ssci.2020.104866

17. Buonanno G, Stabile L, Morawska L. Estimation of airborne viral emission: quanta emission rate of SARS-CoV-2 for infection risk assessment. Environ Int. (2020) 141:105794. doi: 10.1016/j.envint.2020.105794

18. Morawska L, Milton DK. It is time to address airborne transmission of COVID-19. Clin Infect Dis. (2020). doi: 10.1093/cid/ciaa939. [Epub ahead of print].

19. Jayaweera M, Perera H, Gunawardana B, Manatunge J. Transmission of COVID-19 virus by droplets and aerosols: a critical review on the unresolved dichotomy. Environ Res. (2020) 188:109819. doi: 10.1016/j.envres.2020.109819

20. Morawska L, Tang JW, Bahnfleth W, Bluyssen PM, Boerstra A, Buonanno G, et al. How can airborne transmission of COVID-19 indoors be minimised? Environ Int. (2020) 142:105832. doi: 10.1016/j.envint.2020.105832

21. Pasnick S, Carlos WG, Dela Cruz CS, Gross JE, Garrison Jamil S. SARS-CoV2 transmission and the risk of aerosol generating procedures. Am J Respir Crit Care Med. (2020). doi: 10.1164/rccm.2020C11. [Epub ahead of print].

22. McDermott CV, Alicic RZ, Harden N, Cox EJ Scanlan JM. Put a lid on it: are faecal bio-aerosols a route of transmission for SARS-CoV-2? J Hosp Infect. (2020) 105:397-8. doi: 10.1016/j.jhin.2020.04.024

23. Kohanski MA, Lo LJ, Waring MS. Review of indoor aerosol generation, transport and control in the context of COVID-19. Int Forum Allergy Rhinol. (2020) 10:1173-79. doi: 10.1002/alr.22661

24. Fink JB, Ehrmann S, Li J, Dailey P, McKiernan P, Darquenne C, et al. Reducing aerosol-related risk of transmission in the era of COVID-19: an interim guidance endorsed by the international society of aerosols in medicine. J Aerosol Med Pulm Drug Deliv. (2020). doi: 10.1089/jamp.2020.1615. [Epub ahead of print].

25. Johnson GR, Morawska L. The mechanism of breath aerosol formation. J Aerosol Med Pulm Drug Deliv. (2009) 22:229-37. doi: $10.1089 /$ jamp.2008.0720

26. Han ZY, Weng WG, Huang QY. Characterizations of particle size distribution of the droplets exhaled by sneeze. J R Soc Interf. (2013) 10:560. doi: 10.1098/rsif.2013.0560

27. Gralton J, Tovey E, McLaws M-L, Rawlinson WD. The role of particle size in aerosolised pathogen transmission: a review. J Infect. (2011) 62:1-13. doi: 10.1016/j.jinf.2010.11.010

28. Stadnytskyi V, Bax CE, Bax A, Anfinrud P. The airborne lifetime of small speech droplets and their potential importance in SARS-CoV-2 transmission. Proc Natl Acad Sci USA. (2020) 117:11875-7. doi: 10.1073/pnas.2006874117

29. Scheuch G. Breathing is enough: for the spread of influenza virus and SARSCoV-2 by breathing only. J Aerosol Med Pulmon Drug Deliv. (2020) 33:230-4. doi: 10.1089/jamp.2020.1616

30. Asadi S, Wexler AS, Cappa CD, Barreda S, Bouvier NM, Ristenpart WD. Aerosol emission and superemission during human speech increase with voice loudness. Sci Rep. (2019) 9:2348. doi: 10.1038/s41598-019-38808-z

31. Asadi S, Wexler AS, Cappa CD, Barreda S, Bouvier NM, Ristenpart WD. of voicing and articulation manner on aerosol particle emission during human speech. PLoS ONE. (2020) 15:e0227699. doi: 10.1371/journal.pone.0227699

32. Chao CYH, Wan MP, Morawska L, Johnson GR, Ristovski ZD, Hargreaves M. Characterization characterization of expiration air jets and droplet size distributions immediately at the mouth opening. J Aerosol Sci. (2009) 40:122-33. doi: 10.1016/j.jaerosci.2008.10.003
33. Mittal R, Ni R, Seo J-H. The flow physics of COVID-19. J Fluid Mech. (2020) 894:330. doi: $10.1017 / \mathrm{jm} .2020 .330$

34. Bake B, Larsson P, Ljungkvist G, Ljungstrom E, Olin AC. Exhaled particles and small airways. Respir Res. (2019) 20:8. doi: 10.1186/s12931-019-0970-9

35. Morawska L, Johnson GR, Ristovski ZD, Hargreaves M, Mengersen K, Corbett $\mathrm{S}$, et al. Size distribution and sites of origin of droplets expelled from the human respiratory tract during expiratory activities. J Aerosol Sci. (2009) 40:256-69. doi: 10.1016/j.jaerosci.2008.11.002

36. Johnson GR, Morawska L, Ristovski ZD, Hargreaves M, Mengersen K, Chao $\mathrm{CYH}$, et al. Modality of human expired aerosol size distributions. J Aerosol Sci. (2011) 42:839-51. doi: 10.1016/j.jaerosci.2011.07.009

37. Pendar M-R, Pascoa JC. Numerical modeling of the distribution of virus carrying saliva droplets during sneeze and cough. Phys Fluids. (2020) 32:33205. doi: $10.1063 / 5.0018432$

38. Guo Y, Wei J, Ou C, Liu L, Sadrizadeh S, Jin T, et al. Deposition of droplets from the trachea or bronchus in the respiratory tract during exhalation: a steady-state numerical investigation. Aerosol Sci Technol. (2020) 54:869-79. doi: 10.1080/02786826.2020.1772459

39. Giovanni A, Radulesco T, Bouchet G, Mattei A, Revis J, Bogdanski E, et al. Transmission of droplet-conveyed infectious agents such as SARS$\mathrm{CoV}-2$ by speech and vocal exercises during speech therapy: preliminary experiment concerning airflow velocity. Eur Arch Otorhinolaryngol. (2020). 16:1-6. doi: 10.1007/s00405-020-06200-7

40. Fenelly KP. Particle sizes of infectious aerosols: implications for infection control. Lancet Respir Med. (2020) 8:914-24. doi: 10.1016/S2213-2600(20)30323-4

41. Mutuku JK, Hou W-C, Chen W-H. An overview of experiments and numerical simulations on airflow and aerosols deposition in human airways and the role of bioaerosol motion in COVID-19 transmission. Aerosol Air Qual Res. (2020) 20:1172-96. doi: 10.4209/aaqr.2020.04.0185

42. Bao L, Gao H, Deng W, Lv Q, Yu H, Liu M, et al. Transmission of SARS-CoV2 via close contact and respiratory droplets among hACE2 mice. J Infect Dis. (2020) 222:551-5. doi: 10.1093/infdis/jiaa281

43. Somsen GA, van Rijn C, Kooij S, Bem RA, Bonn D. Small droplet aerosols in poorly ventilated spaces and SARS-CoV-2 transmission. Lancet Respir Med. (2020) 7:658-9. doi: 10.1016/S2213-2600(20)30245-9

44. Riediker M, Tsai D-H. Estimation of viral aerosol emissions from simulated individuals with asymptomatic to moderate coronavirus disease 2019. JAMA Network Open. (2020) 3:e2013807. doi: 10.1001/jamanetworkopen.2020.13807

45. Hou YXJ, Okuda K, Edwards CE, Martinez DR, Asakura T, Dinnon KH, et al. SARS-CoV-2 reverse genetics reveals a variable infection gradient in the respiratory tract. Cell. (2020) 182:429-46. doi: 10.1016/j.cell.2020.05.042

46. Dbouk T, Drikakis D. On coughing and airborne droplet transmission to humans. Phys Fluids. (2020) 32:053310. doi: 10.1063/5.0011960

47. Lindsley WG, Blachere FM, Beezhold DH, Thewlis RE, Noorbakhsh B, Othumpangat S. Viable influenza A virus in airborne particles expelled during coughs vs. exhalations. Influenza Other Respir Viruses. (2016) 10:40413. doi: 10.1111 /irv. 12390

48. Riediker M, Morawska L.: Low exhaled breath droplet formation may explain why children are poor SARS-CoV-2 transmitterss. Aerosol Air Qual Res. (2020) 20:1513-5. doi: 10.4209/aaqr.2020.06.0304

49. Korber B, Fischer WM, Gnanakaran S, Yoon H, Theiler J, Abfalterer $\mathrm{W}$, et al. Tracking changes in SARS-CoV-2 Spike: evidence that D614G increases infectivity of the COVID-19 virus. Cell. (2020) 182:812-27 doi: 10.1016/j.cell.2020.06.043

50. Kenyon C. The prominence of asymptomatic superspreaders in transmission mean universal face masking should be part of COVID-19 de-escalation strategies. Int J Infect Dis. (2020) 97:21-2. doi: 10.1016/j.ijid.2020.05.102

51. Fabian P, Brain J, Houseman EA, Gern J, Milton DK. Origin of exhaled breath particles from healthy and human rhinovirus-infected subjects. J Aerosol Med Pulmon Drug Deliv. (2011) 24:137-47. doi: 10.1089/jamp.20 10.0815

52. Woelfel R, Corman VM, Guggemos W, Seilmaier M, Zange S, Mueller MA, et al. Virological assessment of hospitalized patients with COVID-2019. Nature. (2020) 581:465-9. doi: 10.1038/s41586-020-2196-x

53. Zayas G, Chiang MC, Wong E, MacDonald F, Lange CF, Senthilselvan A, et al. Cough aerosol in healthy participants: fundamental knowledge to 
optimize droplet-spread infectious respiratory disease management. BMC Pulmon Med. (2012) 12:11. doi: 10.1186/1471-2466-12-11

54. Schijven J, Vermeulen LC, Swart A, Meijer A, Duizer E, de Roda Husman AM. Exposure assessment for airborne transmission of SARSCoV-2 via breathing, speaking, coughing and sneezing. medRxiv. (2020). doi: $10.1101 / 2020.07 .02 .20144832$

55. Liu L, Wei J, Li Y, Ooi A. Evaporation and dispersion of respiratory droplets from coughing. Indoor Air. (2017) 27:179-90. doi: 10.1111/ina.12297

56. Williams FA. On the assumptions underlying droplet vaporization and combustion theories. J Chem Phys. (1960) 33:133-44. doi: 10.1063/1.1731068

57. Netz RR. Mechanisms of airborne infection via evaporating and sedimenting droplets produced by speaking. J Phys Chem B. (2020) 124:7093-101. doi: 10.1021/acs.jpcb.0c05229

58. Wu JS, Liu YJ, Sheen HJ. Effects of ambient turbulence and fuel properties on the evaporation rate of single droplets. Int J Heat Mass Transfer. (2001) 44:4593-603. doi: 10.1016/S0017-9310(01)00108-9

59. Metzger S, Steil B, Abdelkader M, Klingmuller K, Xu L, Penner JE, et al. Aerosol water parameterisation: a single parameter framework. Atmos Chem Phys. (2016) 16:7213-37. doi: 10.5194/acp-16-7213-2016

60. Yang X, Ou C, Yang H, Liu L, Song T, Kang M, et al. Transmission of pathogen-laden expiratory droplets in a coach bus. J Hazard Mat. (2020) 397:122609. doi: 10.1016/j.jhazmat.2020.122609

61. Feng $\mathrm{Y}$, Marchal T, Sperry $\mathrm{T}, \mathrm{Yi} \mathrm{H}$. Influence of wind and relative humidity on the social distancing effectiveness to prevent COVID-19 airborne transmission: a numerical study. J Aerosol Sci. (2020) 147:105585. doi: 10.1016/j.jaerosci.2020.105585

62. Gal JY, Fovet Y, Adib-Yadzi M. About a synthetic saliva for in vitro studies. Talanta. (2001) 53:1103-15. doi: 10.1016/S0039-9140(00)00618-4

63. Schicht M, Stengl C, Sel S, Heinemann F, Gotz W, Petschelt A, et al. The distribution of human surfactant proteins within the oral cavity and their role during infectious diseases of the gingiva. Ann Anat. (2015) 199:92-7. doi: 10.1016/j.aanat.2014.05.040

64. Burey P, Bhandari BR, Howes T, Gidley MJ. Hydrocolloid gel particles: formation, characterization, and application. Crit Rev Food Sci Nutr. (2008) 48:361-77. doi: 10.1080/10408390701347801

65. Xu Z, Wang T, Che Z. Droplet deformation and breakup in shear flow of air. Phys Fluids. (2020) 32:052109. doi: 10.1063/5.0006236

66. Scharfman BE, Techet AH, Bush JWM, Bourouiba L. Visualization of sneeze ejecta: steps of fluid fragmentation leading to respiratory droplets. Exp Fluids. (2016) 57:24. doi: 10.1007/s00348-015-2078-4

67. Sommerfeld M, Pasternak L. Advances in modelling of binary droplet collision outcomes in sprays: a review of available knowledge. Int J Multiphase Flow. (2019) 117:182-205. doi: 10.1016/j.ijmultiphaseflow.2019.05.001

68. Pak CY, Li WT, Tse YLS. Free energy and dynamics of water droplet coalescence. J Phys Chem C. (2018) 122:22975-84. doi: $10.1021 /$ acs.jpcc. 8 b06507

69. Ristenpart WD, Bird JC, Belmonte A, Dollar F, Stone HA. Noncoalescence of oppositely charged drops. Nature. (2009) 461:377-80. doi: 10.1038 /nature08294

70. Pan KL, Tseng YH, Chen JC, Huang KL, Wang CH, Lai MC. Controlling droplet bouncing and coalescence with surfactant. J Fluid Mech. (2016) 799:603-36. doi: 10.1017/jfm.2016.381

71. Finotello G, Padding JT, Deen NG, Jongsma A, Innings F, et al. Effect of viscosity on droplet-droplet collisional interaction. Phys Fluids. (2017) 29:067102. doi: 10.1063/1.4984081

72. Setti L, Passarini F, De Gennaro G, Barbieri P, Pallavicini A, Ruscio M, et al. Searching for SARS-COV-2 on particulate matter: a possible early indicator of COVID-19 epidemic recurrence. Int J Environ Res Public Health. (2020) 17:2986. doi: 10.3390/ijerph17092986

73. Spencer EA, Brassey J, Jefferson T, Heneghan C. Environmental Weather Conditions and Influence on Transmission of SARS-CoV-2. (2020). Available online at: https://www.cebm.net/covid-19/weather-conditions-sars-cov-2/ (accessed September 21, 2020).

74. Coccia M. Factors determining the diffusion of COVID-19 and suggested strategy to prevent future accelerated viral infectivity similar to COVID. Sci Total Environ. (2020) 729:138474. doi: 10.1016/j.scitotenv.2020.138474

75. Zoran MA, Savastru RS, Savastru DM, Tautan MN. Assessing the relationship between surface levels of PM2.5 and PM10 particulate matter impact on COVID-19 in Milan, Italy. Sci Total Environ. (2020) 738:139825. doi: 10.1016/j.scitotenv.2020.139825

76. Comunian S, Dongo D, Milani C, Palestini P. Air pollution and COVID-19: the role of particulate matter in the spread and sncrease of COVID-19's morbidity and mortality. Int J Environ Res Public Health. (2020) 17:4487. doi: 10.3390/ijerph17124487

77. Yao M, Zhang L, Ma J, Zhou L. On airborne transmission and control of SARS-Cov-2. Sci Total Environ. (2020) 731:139178. doi: 10.1016/j.scitotenv.2020.139178

78. Adhikari A, Yin J. Short-term effects of ambient ozone, PM2.5, and meteorological factors on COVID-19 confirmed cases and deaths in Queens, New York. Int J Environ Res Public Health. (2020) 17:4047. doi: 10.3390/ijerph17114047

79. Ahmadi M, Sharifi A, Dorosti S, Jafarzadeh Ghoushchi S, Ghanbari $\mathrm{N}$. Investigation of effective climatology parameters on COVID19 outbreak in Iran. Sci Total Environ. (2020) 729:138705. doi: 10.1016/j.scitotenv.2020.138705

80. Pope CA, Burnett RT, Thun MJ, Calle EE, Krewski D, Ito K, et al. Lung cancer, cardiopulmonary mortality, and long-term exposure to fine particulate air pollution. JAMA. (2002) 287:1132-41. doi: 10.1001/jama.287.9.1132

81. Grzywa-Celinska A, Krusinski A, Milanowski J. 'Smoging kills' Effects of air pollution on human respiratory system. Ann Agric Environ Med. (2020) 27:1-5. doi: $10.26444 /$ aaem/110477

82. Tigala S, Sharma AR, Sachdeva K. Health risk assessment due to biomass smoke exposure in Indian indoor environment: an empirical approach using lung deposition model. Sci Total Environ. (2018) 640:935-42. doi: 10.1016/j.scitotenv.2018.05.323

83. Rubens JH, Karakousis PC, Jain SK. Stability and viability of SARS-CoV-2. N Engl J Med. (2020) 382:1962-3. doi: 10.1056/NEJMc2007942

84. Biryukov J, Boydston JA, Dunning RA, Yeager JJ, Wood S, Reese $\mathrm{AL}$, et al. Increasing temperature and relative humidity accelerates inactivation of SARS-CoV-2 on surfaces. mSphere. (2020) 5:20. doi: $10.1128 / \mathrm{mSphere} .00441-20$

85. Fears AC, Klimstra WB, Duprex P, Hartman A, Weaver SC, Plante $\mathrm{KC}$, et al. Persistence of severe acute respiratory syndrome coronavirus 2 in aerosol suspensions. Emerg Infect Dis. (2020) 26:2168-71. doi: $10.3201 /$ eid2609.201806

86. Tang JW. The effect of environmental parameters on the survival of airborne infectious agents. J R Soc Interface. (2009) 6:S737-46. doi: 10.1098/rsif.2009.0227.focus

87. Spena A, Palombi L, Corcione M, Carestia M, Spena VA. On the optimal indoor air conditions for SARS-CoV-2 inactivation. An enthalpybased approach. Int J Environ Res Public Health. (2020) 17:6083. doi: 10.3390/ijerph17176083

88. Hijnen WAM, Beerendonk EF, Medema GJ. Inactivation credit of UV radiation for viruses, bacteria and protozoan (oo)cysts in water: a review. Water Res. (2006) 40:3-22. doi: 10.1016/j.watres.2005.10.030

89. Guerrero-Beltran JA, Barbosa-Canovas GV. Review: advantages and limitations on processing foods by UV light. Food Sci Technol Int. (2004) 10:137-47. doi: 10.1177/1082013204044359

90. Qureshi Z, Jones N, Temple R, Larwood JPJ, Greenhalgh T, Bourouiba $\mathrm{L}$. What is the evidence to support the 2-metre social distancing rule to reduce COVID-19 transmission? (2020). Available online aat: https://www. cebm.net/covid-19/what-is-the-evidence-to-support-the-2-metre- socialdistancing-rule-to-reduce-covid-19-transmission/ (accessed September 21, 2020).

91. Halloran SK, Wexler AS, Ristenpart WD. A comprehensive breath plume model for disease transmission via expiratory aerosols. PLoS ONE. (2012) 7:e0037088. doi: 10.1371/journal.pone.0037088

92. Choi JI, Edwards JR. Large-eddy simulation of human-induced contaminant transport in room compartments. Indoor Air. (2012) 22:77-87. doi: $10.1111 / j .1600-0668.2011 .00741 . x$

93. Edge BA, Paterson EG, Settles GS. Computational study of the wake and contaminant transport of a walking human. J Fluids Eng. (2005) 127:967-77. doi: $10.1115 / 1.2013291$

94. Gousseau P, Blocken B, Stathopoulos T, van Heijst GJF. Near-field pollutant dispersion in an actual urban area: analysis of the mass transport mechanism by high-resolution large eddy simulations. Comput Fluids. (2015) 114:151-62. doi: 10.1016/j.compfluid.2015.02.018 
95. Lateb M, Meroney RN, Yataghene M, Fellouah H, Saleh F, Boufadel MC. On the use of numerical modelling for near-field pollutant dispersion in urban environments - a review. Environ Poll. (2016) 208:271-83. doi: 10.1016/j.envpol.2015.07.039

96. Dai H, Zhao B. Association of the infection probability of COVID19 with ventilation rates in confined spaces. Build Simul. (2020). doi: 10.1007/s12273-020-0703-5. [Epub ahead of print].

97. Correia G, Rodrigues L, Gameiro da Silva M, Goncalves T. Airborne route and bad use of ventilation systems as non-negligible factors in SARS-CoV-2 transmission. Med Hypoth. (2020) 141:109781. doi: 10.1016/j.mehy.2020.109781

98. Chirico F, Sacco A, Bragazzi NL, Magnavita N. Can air-conditioning systems contribute to the spread of SARS/MERS/COVID-19 infection? Insights from a rapid review of the literature. Int J Environ Res Public Health. (2020) 17:6052. doi: 10.3390/ijerph17176052

99. Escombe AR, Oeser CC, Gilman RH, Navincopa M, Ticona E, Pan W, et al. Ventilation for the prevention of airborne contagion. PLoS Med. (2007) 4:309-17. doi: 10.1371/journal.pmed.0040068

100. Li Y, Leung GM, Tang JW, Yang X, Chao CYH, Lin JZ, et al. Role of ventilation in airborne transmission of infectious agents in the built environment-a multidisciplinary systematic review. Indoor Air. (2007) 17:2-18. doi: 10.1111/j.1600-0668.2006.00445.x

101. Zhang JJ. Integrating IAQ control strategies to reduce the risk of asymptomatic SARS CoV-2 infections in classrooms and open plan offices. Sci Technol Built Environ. (2020) 26:1013-8. doi: 10.1080/23744731.2020.1794499

102. Dietz L, Horve PF, Coil DA, Fretz M, Eisen JA, Van Den Wymelenberg K. 2019 novel coronavirus (COVID-19) pandemic: built environment considerations to reduce transmission. mSystems. (2020) 5:15. doi: $10.1128 / \mathrm{mSystems} .00245-20$

103. REHVA. COVID-19 guidance document How to operate and use building services in order to prevent the spread of the coronavirus disease (COVID-19) virus (SARS-CoV-2) in workplaces. (2020). Available online at: https:// www.rehva.eu/fileadmin/user_upload/REHVA_COVID-19_guidance_ document_V3_03082020.pdf (accessed September 21, 2020).

104. REHVA. Literature REHVA COVID-19 guidance document (version April 3, 2020). (2020). Available online at: https://www.rehva.eu/fileadmin/ user_upload/REHVA_Literature_COVID-19_guidance_document_ver2_ 20200403_01.pdf (accessed September 21, 2020).

105. CIBSE. Coronavirus, SARS-CoV-2, COVID-19 and HVAC Systems. (2020). Available online at: https://www.cibse.org/coronavirus-covid19/coronavirus-covid-19-and-hvac-systems (accessed September 21, 2020).

106. You R, Lin C-H, Wei D, Chen Q. Evaluating the commercial airliner cabin environment with different air distribution systems. Indoor Air. (2019) 29:840-53. doi: 10.1111/ina.12578

107. Nazarenko Y. Air filtration and severe acute respiratory syndrome coronavirus 2. Epidem Health. (2020) 42:e2020049. doi: 10.4178/epih.e2020049

108. Christopherson DA, Yao WC, Lu M, Vijayakumar R, Sedaghat AR. Highefficiency particulate air filters in the era of COVID-19: function and efficacy. Otolaryngology. (2020). doi: 10.1177/0194599820941838. [Epub ahead of print].

109. Zhao BB, Liu Y, Chen C. Air purifiers: a supplementary measure to remove airborne SARS-CoV-2. Build Environ. (2020) 177:106918. doi: 10.1016/j.buildenv.2020.106918

110. Escombe AR, Ticona E, Chávez-Pérez V, Espinoza M, Moore DAJ. Improving natural ventilation in hospital waiting and consulting rooms to reduce nosocomial tuberculosis transmission risk in a low resource setting. BMC Infect Dis. (2019) 19:88. doi: 10.1186/s12879-0193717-9

111. Chen Q. Can we migrate COVID-19 spreading risk? Front Environ Sci Eng. (2021) 15:35. doi: 10.1007/s11783-020-1328-8

112. Garcia de Abajo FJ, Javier Hernandez R, Kaminer I, Meyerhans A, RosellLlompart J, Sanchez-Elsner T. Back to normal: an old physics route to reduce SARS-CoV-2 transmission in indoor spaces. ACS Nano. (2020) 14:7704-13. doi: 10.1021/acsnano.0c04596

113. Garcia de Abajo FJ, Javier Hernandez R, Kaminer I, Meyerhans A, RosellLlompart J, Sanchez-Elsner T. Estimated inactivation of coronaviruses by solar radiation with special reference to COVID-19. Photochem Photobiol. (2020) 96:731-7. doi: 10.1111/php.13293

114. Middleton J, Reintjes R, Lopes $H$. Meat plants-a new front line in the covid-19 pandemic. BMJ. (2020) 370:m2716. doi: 10.1136/bmj.m2716

115. Gross A, Bott I. The Radical Technologies to Keep Offices Clear of Coronavirus. London: Financial Times. (2020). Available online at: https://www.ft.com/ content/c4de006e-c483-4a9c-88d7-0373e2a3c9c0 (accessed September 21, 2020).

116. Buonanno M, Welch D, Shuryak I, Brenner DJ. Far-UVC light (222 nm) efficiently and safely inactivates airborne human coronaviruses. Sci Rep. (2020) 10:10285. doi: 10.1038/s41598-020-67211-2

117. Nardell EA, Nathavitharana RR. Airborne spread of SARS-CoV2 and a potential role for air disinfection. JAMA. (2020) 324:141-2. doi: 10.1001/jama.2020.7603

118. Chu DK, Akl EA, Duda S, Solo K, Yaacoub S, Schunemann HJ, et al. Physical distancing, face masks, and eye protection to prevent person-to-person transmission of SARS-CoV-2 and COVID-19: a systematic review and metaanalysis. Lancet. (2020) 395:1973-87. doi: 10.1016/j.jvs.2020.07.040

119. Fisman DN, Greer AL, Tuite AR. Bidirectional impact of imperfect mask use on reproduction number of COVID-19: a next generation matrix approach. Infect Dis Model. (2020) 5:405-8. doi: 10.1016/j.idm.2020.06.004

120. Chua MH, Cheng W, Goh SS, Kong J, Li B, Lim JYC, et al. Face masks in the new COVID-19 normal: Materials, testing, and perspectives. Research. (2020) 2020:7286735. doi: 10.34133/2020/7286735

121. Konda A, Prakash A, Moss GA, Schmoldt M, Grant GD, Guha S. Aerosol filtration efficiency of common fabrics used in respiratory cloth masks. ACS Nano. (2020) 14:6339-47. doi: 10.1021/acsnano.0c03252

122. Kahler CJ, Hain R. Fundamental protective mechanisms of face masks against droplet infections. J Aerosol Sci. (2020) 148:105617. doi: 10.1016/j.jaerosci.2020.105617

123. Pleil JD, Beauchamp JD, Risby TH, Dweik RA. The scientific rationale for the use of simple masks or improvised facial coverings to trap exhaled aerosols and possibly reduce the breathborne spread of COVID-19. J Breath Res. (2020) 14:030201. doi: 10.1088/1752-7163/ab8a55

124. Sanchez AL, Hubbard JA, Dellinger JG, Servantes BL. Experimental study of electrostatic aerosol filtration at moderate filter face velocity. Aerosol Sci Technol. (2013) 47:606-15. doi: 10.1080/02786826.2013.778384

125. Leung WW-F, Sun Q. Charged PVDF multilayer nanofiber filter in filtering simulated airborne novel coronavirus (COVID-19) using ambient nano-aerosols. Sep Purif Technol. (2020) 245:116887. doi: 10.1016/j.seppur.2020.116887

126. Zangmeister CD, Radney JG, Vicenzi EP, Weaver JL. Filtration efficiencies of nanoscale aerosol by cloth mask materials used to slow the spread of SARS CoV-2. ACS Nano. (2020) 14:9188-200. doi: 10.1021/acsnano.0c05025

127. Lustig SR, Biswakarma JJH, Rana D, Tilford SH, Hu W, Su M, et al. Effectiveness of common fabrics to block aqueous aerosols of virus-like nanoparticles. ACS Nano. (2020) 14:7651-8. doi: 10.1021/acsnano.0c03972

128. Verma S, Dhanak M, Frankenfield J. Visualizing the effectiveness of face masks in obstructing respiratory jets. Phys Fluids. (2020) 32:061708. doi: $10.1063 / 5.0016018$

129. Amendola L, Saurini MT, Di Girolamo F, Arduini F. A rapid screening method for testing the efficiency of masks in breaking down aerosols. Microchem J. (2020) 157:104928. doi: 10.1016/j.microc.2020.104928

130. Schilling K, Gentner DR, Wilen L, Medina A, Buehler C, Perez-Lorenzo LJ, et al. An accessible method for screening aerosol filtration identifies poorperforming commercial masks and respirators. J Expo Sci Environ Epidemiol. (2020). doi: 10.1038/s41370-020-0258-7. [Epub ahead of print].

Conflict of Interest: The author declares that the research was conducted in the absence of any commercial or financial relationships that could be construed as a potential conflict of interest.

Copyright (c) 2020 Jarvis. This is an open-access article distributed under the terms of the Creative Commons Attribution License (CC BY). The use, distribution or reproduction in other forums is permitted, provided the original author(s) and the copyright owner(s) are credited and that the original publication in this journal is cited, in accordance with accepted academic practice. No use, distribution or reproduction is permitted which does not comply with these terms. 